\title{
Bacteriological profiles and drug susceptibility of Streptococcus isolated from conjunctival sac of healthy children
}

\author{
Ruili Ke', Min Zhang ${ }^{2}$, Qin Zhou', Yunfei Yang ${ }^{1}$, Ruifen Shen'1, Huipin Huang ${ }^{1}$ and Xiangrong Zhang ${ }^{1 *}$
}

\begin{abstract}
Background: To investigate bacterial flora and antibiotics susceptibility of Streptococcus pneumoniae isolated from the conjunctival sac of heathy children.

Methods: Bacteria were isolated from the secretions of conjunctival sac of healthy children between 2015 and 2018. Antimicrobial susceptibility of isolated S. pneumoniae strains were determined using microbroth dilution method.

Results: The sac secretions were collected from a total of 6440 children. 1409 samples presented bacterial growth, accounting for $21.8 \%$ of the samples. Among the 22 bacterial species isolated, 528 samples presented Grampositive Staphylococcus spp. growth, accounting for $37.4 \%$ of the isolates, followed by Corynebacterium spp., counting for $30 \%$ of the isolates and Streptococcus pneumoniae, counting for $21.4 \%$ of the isolates. Antibiotics susceptibility tests showed that the majority of $S$. pneumoniae isolates were sensitive to most antibiotics tested. However, 72.8 and $81.2 \%$ of the isolates were resistant to erythromycin and tetracycline, respectively, and over 10\% of them were resistant to gentamicin, tobramycin and rifampicin.

Conclusions: The bacterial flora of healthy children is mainly consisted of Gram-positive bacteria belonging to Corynebacterium spp. and Streptococcus spp.; most of S. pneumoniae isolates were sensitive to antibiotics except erythromycin and tetracycline.
\end{abstract}

Keywords: Conjunctival sac; bacterial flora, Antimicrobial susceptibility, Antibiotics

\section{Background}

The conjunctival sac is the space bound between the palpebral and bulbar conjunctiva. It directly contacts the external environment and is connected to the skin. Due to the structure of conjunctival sac, it inevitably exposes to bacterial sources and may get infected. However, the lacrimal fluid in the conjunctival sac contains antibacterial agents such as immunoglobulins and components of the complement pathways such as lactoferrin, lysozymes

\footnotetext{
* Correspondence: xie22331254@tom.com

'Department of Ophthalmology, The People's Hospital of Longhua, 38 Jianshe East Road, Shenzhen 518000, China

Full list of author information is available at the end of the article
}

and B-lysin, which also have antimicrobial activity $[1,2]$. Therefore, bacteria in the sac would be able to cause eye infections [3]. However, eye infections such as keratitis, dacryocystitis and endophthalmitis may occur when the eyes are subjected to trauma, surgery or compromised immunity [2,4]. A better understand of microbial flora is important to develop appropriate health and preventive measures, particularly for children. Although there are a number of studies reporting the presence of bacteria in the conjunctival sac, these works were conducted in patients suffering from various eye diseases, such as Stevens - Johnson syndrome and cataracts $[5,6]$. These works show that the microbial flora may change

C C The Author(s). 2020 Open Access This article is licensed under a Creative Commons Attribution 4.0 International License, which permits use, sharing, adaptation, distribution and reproduction in any medium or format, as long as you give appropriate credit to the original author(s) and the source, provide a link to the Creative Commons licence, and indicate if changes were made. The images or other third party material in this article are included in the article's Creative Commons licence, unless indicated otherwise in a credit line to the material. If material is not included in the article's Creative Commons licence and your intended use is not permitted by statutory regulation or exceeds the permitted use, you will need to obtain permission directly from the copyright holder. To view a copy of this licence, visit http://creativecommons.org/licenses/by/4.0/ The Creative Commons Public Domain Dedication waiver (http://creativecommons.org/publicdomain/zero/1.0/) applies to the data made available in this article, unless otherwise stated in a credit line to the data. 
as a result of surgery [7, 8], use of antibiotics [9] and even seasonal change. For instance, it was found that conjunctival bacteria in patients undergoing cataract surgery presented a seasonal prevalence pattern where different bacteria were identified in different seasons [10]. In addition, use of antibiotics is also found to change drug resistance in conjunctival bacteria as well as the microbial flora $[11,12]$. These findings suggest that it is necessary to investigate the microbial flora in specific population to design rationale strategy for eye infection control.

Streptococcus is an important pathogen that causes panophthalmitis [13] and other diseases [14]. However, the distribution and drug resistance of Streptococcus in the conjunctival sac of children are rarely reported. In this study, we investigated the distribution of bacteria, especially Streptococcus, in 6440 healthy, pre-school children who visited our hospital located in southern China and analyzed the drug resistance of S. pneumoniae isolates. The findings would help develop effective and preventive measures to minimize ocular infections and diseases in child.

\section{Methods}

\section{Subjects}

Conjunctival sac secretions of the conjunctival sac were collected from Children visiting our hospital between May 2015 and June 2018. They were aged 0 to 6 years and visiting the hospital for eye examination, elective strabismus, refraction, cataract surgery with no clinical signs of ocular infection. They were excluded if the eye and physical examination showed ocular infections, erythema, edema or other infections-related symptoms. Children who used systemic antibiotics or local antibiotics or eye infection controls within a month were excluded. In addition, children with systemic or immunodeficiency diseases, lacrimal sac, lacrimal abnormalities and other congenital diseases were also excluded. The protocol of this study was approved by the ethics committee of The People's Hospital of Longhua in accordance with the Declaration of Helsinki. Informed written consent was obtained from the parents of children for the study.

\section{Sampling collection and bacterial culture}

The secretion samples were collected using sterile cotton swabs moistened with sterile saline after local cleaning with sterile saline. Secretion were collected from the inside to outside surfaces of the conjunctival fornix by gently pressing and kneading the swabs from one randomly selected eye. Care was taken not to touch the edge of the eyelid during the procedure and to ensure that the child does not blink. The collected specimens were immediately inoculated on blood and chocolate plates and incubated at $35 \pm 2{ }^{\circ} \mathrm{C}$ for $24 \mathrm{~h}$. For chocolate plates, culture was performed in $5 \% \mathrm{CO}_{2}$. The cultures were smeared, stained and examined under microscope to identify the bacteria. Bacterial strains were identified using Micro Scan Autoscan-4 system (Siemens Healthcare, Germany).

\section{Antibiotic resistance assay}

Antimicrobial susceptibility tests were performed according to the Clinical and Laboratory Standards Institute (CLSI) protocols [15]. The assays were conducted on an automatic TDR-200B Bacterial and Antibiotics Susceptibility Analyzer (Jinyang Technology, Beijing, China). Broth microdilution method was used to assay the susceptibility of bacterial stains to antibiotics. Staphylococcus aureus (ATCC29213), S. pneumoniae (ATCC49619), H. influenza (ATCC49247), Pseudomonas aeruginosa (ATCC27853), Escherichia coli (ATCC25 922), Enterococcus faecalis (ATCC29212) were used as quality control strains. The susceptibility of tested strains were classified according to the CLSI standards [15].

\section{Statistical analysis}

Data were analyzed using Microsoft Excel 2003. The normality of distribution of continuous variables was tested by one-sample Kolmogorov-Smirnov test. Continuous variables with normal distribution were presented as mean \pm standard deviation (SD); Means of 2 continuous normally distributed variables were compared by independent samples Student's $t$ test. The frequencies of categorical variables were compared using Pearson $X^{2}$. A value of $P<0.05$ was considered significant.

\section{Results}

\section{Isolation rate}

A total of 6440 samples were collected and analyzed from 3100 (48.1\%) girls and 3340 (51.9\%) boys, with an average age of $3.12 \pm 1.44$. A total of 1409 isolates were obtained with an overall isolation rate of $21.8 \%$. Among them, 646 (45.8\%) were from girls and $763(54.2 \%)$ were from boys. The isolation rates were 18.3, 22.2 and $20.1 \%$ for children between ages 0 and 2, 2 and 4, and 4 and 6, respectively, and were statistically similar $(P>0.05)$ between the age groups.

\section{Bacterial isolates}

Based on microbiological analysis with aid of MicroScan Autoscan-4 system, twenty-two bacterial species were identified. Among them, 528 isolates were Grampositive Staphylococcus spp. (including S. epidermidis, S. aureus, S. hominis and S. haemolyticus) counting for $37.4 \%$ of all isolates, followed by Corynebacterium spp., 
counting for $30 \%$ of the isolates and Streptococcus pneumoniae, counting for $21.4 \%$ of the isolates (Table 1). In other Gram-positive bacteria, Mycobacterium xerosis conjunctiva was the most common one $(n=17)$. When the bacterial species in the Gram-positive samples were further categorized, it was found that S. epidermidis and S. saprophyticus accounted for 21.6 and $8.5 \%$ of the 1409 children isolates.

Isolation rate of Gram-negative bacteria was $8.6 \%$, and among them most were bacteria belonging to Moraxella spp. and Neisseria gonorrhoeae $(n=8)$, Haemophilus influenzae $(n=12)$, and E. coli $(n=4)$ were also detected (Table 1).

\section{Antimicrobial susceptibility}

The antimicrobial susceptibility of $S$. pneumoniae isolates was assayed against 17 antibiotics and the results showed that the majority of isolates could be classified as susceptible to most antibiotics tested based on the CLSI standards [15] (Table 2). All over 95\% isolates tested were susceptible to ofloxacin, ceftriaxone, vancomycin, linezolid and levofloxacin. However, 72.8 and $81.2 \%$ of them were resistant to erythromycin and tetracycline, respectively. In addition, over $10 \%$ of them were resistant to gentamicin, tobramycin and rifampicin and these isolates also had relatively higher percentages with intermediate susceptibility (Table 2).

\section{Discussion}

Previous studies have demonstrated that Staphylococcus and Streptococcus are the main pathogens of bacterial conjunctivitis, with $S$. aureus and $S$. viridans identified as the most common species in neonatal bacterial conjunctivitis [16, 17]. However, bacterial flora in healthy

Table 1 Isolation of conjunctival bacteria from healthy children aged 0 to 6 years

\begin{tabular}{lll}
\hline Bacteria & $\begin{array}{l}\text { No. } \\
\text { isolates }\end{array}$ & $\begin{array}{l}\text { Percentage } \\
(\%)\end{array}$ \\
\hline Gram-positive & 422 & 30.0 \\
Corynebacterium spp. & 305 & 21.6 \\
Staphylococcus epidermidis & 120 & 8.5 \\
Staphylococcus saprophyticus & 68 & 4.8 \\
Staphylococcus aureus & 21 & 1.5 \\
Staphylococcus hominis & 14 & 1.0 \\
Staphylococcus haemolyticus & 301 & 21.4 \\
Streptococcus pneumoniae & 37 & 2.6 \\
Other Gram-positive bacteria & & 0.0 \\
Gram-negative & 97 & 6.9 \\
Moraxella spp. & 24 & 1.7 \\
Other Gram-negative bacteria & &
\end{tabular}

children is rarely reported. A better understanding of bacterial flora and their susceptibility to antibiotics is important for prevention and treatment of bacterial conjunctivitis and rationale use of preventive antibiotics in eye surgery for sterilization of conjunctival sac. Our work shows that Gram-positive corynebacterium, Staphylococcus and Streptococcus were the dominant bacteria in the conjunctival sacs and Gram-negative bacteria were rare. Most of the S. pneumoniae isolates were susceptible to antibiotics tested except erythromycin and tetracycline to which most of the $S$. pneumoniae isolates were resistant.

Streptococcus is commonly found in the mouth, nasopharynx and eye of healthy subjects [18]. Under normal conditions, it is not pathogenic. However, after eye surgery, under compromised immunity, due to abuse of antibiotics or changed ocular microenvironment, conjunctival Streptococcus may result in infections, leading to conjunctivitis and even the breakage of corneal tissue [19]. In addition, bacteria in the conjunctival sac may cause keratitis, dacryocystitis and endophthalmitis in traumatic and surgical conditions [2, 4].

A total of 1409 bacterial isolates were obtained from the conjunctival sac samples with a total isolation rate of $21.9 \%$. The predominant species were Gram positive Corynebacterium spp., Staphylococcus spp. and S. pneumoniae. This bacterial profile is very different from that of adult, where Streptococcus is less frequently found in the conjunctival sac [20], suggesting that Streptococcus is not only common in the nasopharynx of children, but also in the conjunctival sac, especially in infants under 6 years old. In addition, the difference in bacterial profiles between children and adults may be attributed to their difference in the immunity, tear composition, tear fluid hydrodynamics, exposing environment, antibiotics use, bacterial flora in the skin and upper respiratory tract $[21,22]$. Previous studies showed that a number of factors are playing role in protecting eye from bacterial infections, including antimicrobial peptides [23], antimicrobial proteins $[24,25]$ and innate defense pathways [26]. In addition, the bacterial flora may also change chronologically. For example, the patterns of bacterial pathogens in neonatal bacterial conjunctivitis in Southern China has changed during the past 15 years. The number of cases involving Grampositive bacteria exhibited a decreasing trend, whereas those with Gram-negative bacteria showed a growing trend in children with acute neonatal bacterial conjunctivitis [27].

Better understanding of antibiotics resistance is important for rationale use of antibiotics in preventive and therapeutic measures for child. Since S. pneumoniae is not only an important pathogen that causes ocular 
Table 2 Antibiotic susceptibility of Streptococcus pneumoniae isolated from healthy children aged 0 to 6 years

\begin{tabular}{|c|c|c|c|c|c|c|c|}
\hline \multirow[t]{2}{*}{ Antibiotics } & \multirow[t]{2}{*}{ Total no. isolates tested } & \multicolumn{2}{|c|}{ Susceptible } & \multicolumn{2}{|c|}{ Intermediate } & \multicolumn{2}{|c|}{ Resistant } \\
\hline & & No. & $\%$ & No. & $\%$ & No. & $\%$ \\
\hline Penicillin & 261 & 235 & 90.0 & 19 & 7.3 & 7 & 2.7 \\
\hline Hydrobenzylcillin & 210 & 188 & 89.5 & 15 & 7.3 & 7 & 3.2 \\
\hline Gentamicin & 222 & 178 & 80.2 & 21 & 9.5 & 23 & 10.4 \\
\hline Tobramycin & 310 & 239 & 77 & 26 & 8.5 & 45 & 14.5 \\
\hline Erythromycin & 220 & 57 & 25.9 & 3 & 1.3 & 160 & 72.8 \\
\hline Rifampicin & 215 & 163 & 75.6 & 26 & 12.3 & 26 & 12.1 \\
\hline Chloramphenicol & 255 & 181 & 71.1 & 0 & 0 & 74 & 28.9 \\
\hline Gatifloxacin & 240 & 192 & 80.0 & 29 & 12.1 & 19 & 7.9 \\
\hline Ciprofloxacin & 226 & 177 & 78.3 & 30 & 13.1 & 19 & 8.6 \\
\hline Ofloxacin & 199 & 195 & 97.8 & 2 & 1.2 & 2 & 1 \\
\hline Ceftriaxone & 190 & 183 & 96.2 & 4 & 2 & 3 & 1.8 \\
\hline Cefepime & 200 & 184 & 92.2 & 10 & 5 & 6 & 2.8 \\
\hline Vancomycin & 218 & 218 & 100 & 0 & 0 & 0 & 0 \\
\hline Linezolid & 259 & 257 & 99.1 & 2 & 0.9 & 0 & 0 \\
\hline Tetracycline & 288 & 35 & 12.1 & 19 & 6.7 & 234 & 81.2 \\
\hline Levofloxacin & 287 & 286 & 99.5 & 0 & 0 & 1 & 0.5 \\
\hline Gatifloxacin & 311 & 281 & 90.5 & 21 & 6.6 & 9 & 2.9 \\
\hline
\end{tabular}

infections [28] but also is associated with a high degree of morbidity and mortality in many countries around the world and is considered the main cause of death of millions children in the transition countries [29]. We tested the susceptibility of the isolates against commonly available antibiotics and we observed that the majority of Streptococcus isolates obtained from the conjunctival sac are sensitive to the antibiotics tested, particularly to ofloxacin, ceftriaxone, vancomycin, linezolid and levofloxacin. However, 72.8 and $81.2 \%$ of them are resistant to erythromycin and tetracycline, respectively. The rates are higher than those reported previously for infants aged 0 to 1 year [30].

Resistance to erythromycin and tetracycline have been higher [31,32], it demonstrates the widespread presence of transposons in pneumococcal populations, typified by Tn1545. Previous studies showed insertion over time of resistance determinants, such as $\operatorname{erm}(\mathrm{B})$ for erythromycin and aphA3 for kanamycin, into primitive grampositive conjugative transposons carrying tet $(\mathrm{M})$ and the integrase gene int-Tn, typified by $\operatorname{Tn} 916$ [33, 34]. Therefore, for pre-operative local sterilization for eye surgery and for prophylaxes, aminosaccharides and quinolones are recommended and erythromycin and tetracycline should be avoided.

\section{Conclusions}

Our study shows that Streptococcus as well as other Gram-positive bacteria are commonly present in the eye of healthy children. Although most pneumococcal isolates are sensitive to antibiotics, there are strains that are resistant to erythromycin and tetracycline, as well as gentamicin, tobramycin and rifampicin. These results could be used in the selection of empirical therapy if it is not possible to perform susceptibility testing and for developing public health strategies for pre-school children.

\section{Abbreviations \\ CLSI: Clinical and Laboratory Standards Institute; SD: Standard deviation}

Acknowledgements

none.

\section{Authors' contributions}

RK, and XZ designed the study. RK, MZ, QZ, YY and RS collected the data and performed analysis. RK and $\mathrm{HH}$ drafted the manuscript. All authors read and approved the final manuscript.

\section{Funding}

None.

Availability of data and materials

The datasets used during the current study are available from the corresponding author on reasonable request.

Ethics approval and consent to participate

This study was approved by the ethical committee of. The People's Hospital of Longhua. Informed written consent was obtained from the parents or guardian of participants in the study.

Consent for publication Not applicable. 


\section{Competing interests}

The authors declare that they have no competing interests.

\section{Author details}

'Department of Ophthalmology, The People's Hospital of Longhua, 38 Jianshe East Road, Shenzhen 518000, China. ${ }^{2}$ Research Institute of Shenzhen Children's Hospital, Shenzhen, China.

Received: 30 November 2019 Accepted: 12 June 2020

Published online: 22 June 2020

\section{References}

1. Baum J, Barza M. The evolution of antibiotic therapy for bacterial conjunctivitis and keratitis: 1970-2000. Cornea. 2000;19(5):659-72.

2. Sharma PD, Sharma N, Gupta RK, Singh P. Aerobic bacterial flora of the normal conjunctiva at high altitude area of Shimla Hills in India: a hospital based study. Int J Ophthalmol. 2013;6(5):723-6.

3. Wagner RS. Results of a survey of children with acute bacterial conjunctivitis treated with trimethoprim-polymyxin B ophthalmic solution. Clin Ther. 1995; 17(5):875-81.

4. Recchia FM, Busbee BG, Pearlman RB, Carvalho-Recchia CA, Ho AC. Changing trends in the microbiologic aspects of postcataract endophthalmitis. Arch Ophthalmol. 2005;123(3):341-6.

5. Sahin A, Yildirim N, Gultekin S, Akgun Y, Kiremitci A, Schicht M, Paulsen F. Changes in the conjunctival bacterial flora of patients hospitalized in an intensive care unit. Arq Bras Oftalmol. 2017:80(1):21-4.

6. Frizon L, Araújo M, Andrade L, Yu M, Wakamatsu T, Höfling-Lima A, Gomes J. Evaluation of conjunctival bacterial flora in patients with Stevens-Johnson Syndrome. Clinics (Sao Paulo). 2014;69(3):168-72.

7. Eshraghi B, Masoomian B, Izadi A, Abedinifar Z, Falavarjani KG. Conjunctival bacterial flora in nasolacrimal duct obstruction and its changes after successful dacryocystorhinostomy surgery. Ophthalmic Plast Reconstr Surg. 2014:30(1):44-6.

8. Fahmy JA, Moller S, Bentzon MW: Bacterial flora in relation to cataract extraction. III. Postoperative flora. Acta Ophthalmol 1975, 53(5):765-780.

9. Ohtani S, Shimizu K, Nejima R, Kagaya F, Aihara M, Iwasaki T, Shoji N, Miyata K. Conjunctival Bacteria Flora of Glaucoma patients during long-term administration of prostaglandin analog drops. Invest Ophthalmol Vis Sci. 2017:58(10):3991-6.

10. Rubio EF. Climatic influence on conjunctival bacteria of patients undergoing cataract surgery. Eye (Lond). 2004;18(8):778-84.

11. Smith $\mathrm{CH}$. Bacteriology of the healthy conjunctiva. Eye Ear Nose Throat Mon. 1955:34(9):580-5.

12. Nejima R, Shimizu K, Ono T, Noguchi Y, Yagi A, Iwasaki T, Shoji N, Miyata K. Effect of the administration period of perioperative topical levofloxacin on normal conjunctival bacterial flora. J Cataract Refract Surg. 2017;43(1):42-8.

13. Hagiya H, Semba T, Morimoto T, Yamamoto N, Yoshida H, Tomono K. Panophthalmitis caused by Streptococcus dysgalactiae subsp. equisimilis: a case report and literature review. J Infect Chemother. 2018;24(11):936-40.

14. Attisano C, Cibinel M, Strani G, Panepinto G, Pollino C, Furfaro G, Giardini F, Machetta F, Grignolo FM, Grandi G. Severe ocular bacterial infections: a retrospective study over 13 years. Ocul Immunol Inflamm. 2017;25(6):825-9.

15. Institute CaLS: Performance standards for antimicrobial susceptibility testing. 2016.

16. Ghosh S, Chatterjee BD, Chakraborty CK, Chakravarty A, Khatua SP. Bacteria in surface infections of neonates. J Indian Med Assoc. 1995;93(4):132-5.

17. Dannevig L, Straume B, Melby K: Ophthalmia neonatorum in northern Norway. II. Microbiology with emphasis on chlamydia trachomatis. Acta Ophthalmol 1992, 70(1):19-25.

18. Aas JA, Paster BJ, Stokes LN, Olsen I, Dewhirst FE. Defining the normal bacterial flora of the oral cavity. J Clin Microbiol. 2005;43(11):5721-32.

19. Epling J. Bacterial conjunctivitis. BMJ Clin Evid. 2012;2012.

20. Tao H, Wang J, Li L, Zhang HZ, Chen MP, Li L. Incidence and antimicrobial sensitivity profiles of Normal conjunctiva bacterial Flora in the central area of China: a hospital-based study. Front Physiol. 2017:8:363.

21. Chandler JW, Gillette TE. Immunologic defense mechanisms of the ocular surface. Ophthalmology. 1983;90(6):585-91.

22. Knop E, Knop N. Anatomy and immunology of the ocular surface. Chem Immunol Allergy. 2007;92:36-49.
23. Abedin A, Mohammed I, Hopkinson A, Dua HS. A novel antimicrobial peptide on the ocular surface shows decreased expression in inflammation and infection. Invest Ophthalmol Vis Sci. 2008;49(1):28-33.

24. Mohammed I, Suleman H, Otri AM, Kulkarni BB, Chen P, Hopkinson A, Dua HS. Localization and gene expression of human beta-defensin 9 at the human ocular surface epithelium. Invest Ophthalmol Vis Sci. 2010;51(9): 4677-82.

25. Evans DJ, Fleiszig SM. Why does the healthy cornea resist Pseudomonas aeruginosa infection? Am J Ophthalmol. 2013;155(6):961-70 e962.

26. Mun JJ, Tam C, Evans DJ, Fleiszig SM. Modulation of epithelial immunity by mucosal fluid. Sci Rep. 2011:1:8.

27. Tang S, Li M, Chen H, Ping G, Zhang C, Wang S. A chronological study of the bacterial pathogen changes in acute neonatal bacterial conjunctivitis in southern China. BMC Ophthalmol. 2017;17(1):174.

28. Teweldemedhin M, Gebreyesus H, Atsbaha AH, Asgedom SW, Saravanan M. Bacterial profile of ocular infections: a systematic review. BMC Ophthalmol. 2017;17(1):212.

29. Karcic E, Aljicevic M, Bektas S, Karcic B. Antimicrobial susceptibility/resistance of Streptococcus Pneumoniae. Mater Soc. 2015;27(3):180-4.

30. Li L. Analysis of the results of separation and antimicrobial susceptibility tests of infant eye secretions of Streptococcus Pneumoniae. Medical Innovation of Chin. 2015:12(9):106-8.

31. Montanari MP, Cochetti I, Mingoia M, Varaldo PE. Phenotypic and molecular characterization of tetracycline- and erythromycin-resistant strains of Streptococcus pneumoniae. Antimicrob Agents Chemother. 2003;47(7): 2236-41.

32. Doern GV, Heilmann KP, Huynh HK, Rhomberg PR, Coffman SL, Brueggemann AB. Antimicrobial resistance among clinical isolates of Streptococcus pneumoniae in the United States during 1999--2000, including a comparison of resistance rates since 1994--1995. Antimicrob Agents Chemother. 2001;45(6):1721-9.

33. Chopra I, Roberts M. Tetracycline antibiotics: mode of action, applications, molecular biology, and epidemiology of bacterial resistance. Microbiol Mol Biol Rev. 2001;65(2):232-60 second page, table of contents.

34. Clewell DB, Flannagan SE, Jaworski DD. Unconstrained bacterial promiscuity: the Tn916-Tn1545 family of conjugative transposons. Trends Microbiol. 1995;3(6):229-36.

\section{Publisher's Note}

Springer Nature remains neutral with regard to jurisdictional claims in published maps and institutional affiliations.

Ready to submit your research? Choose BMC and benefit from:

- fast, convenient online submission

- thorough peer review by experienced researchers in your field

- rapid publication on acceptance

- support for research data, including large and complex data types

- gold Open Access which fosters wider collaboration and increased citations

- maximum visibility for your research: over $100 \mathrm{M}$ website views per year

At BMC, research is always in progress.

Learn more biomedcentral.com/submission 